\title{
Collection and prevalence of ticks in cattles and buffaloes from free-range management systems of Islamabad
}

\author{
Zawar Ahmad', Zahid Anwar ${ }^{1 *}$ (D) Mian Adnan², Nida Imtiaz , Haroon Ur Rashid ${ }^{3}$ and Faryal Gohar ${ }^{2}$
}

\begin{abstract}
Background: In recent decades, parasitism has remained one of the major problems of dairy industry in Pakistan. In this context, the most common tick species prevailing is Hyalomma, Boophilus, Haemaphysalis, and Rhipicephalus.

Result: High prevalence was found in cow $20.83 \%$ as compared to buffaloes. Over all prevalence of ticks was found as $11.3 \%$ whereas no ticks were found from LRS (livestock research station), and Malpur showed higher prevalence (8.67\%). Breed wise tick prevalence showed that crossbred cattle was heavily infested (39.53\%) while pure bred indigenous cattle was mildly infested (3.03\%). Three tick genera found were Hyalomma with high prevalence rate 6.63\% and Rhipicephalus and Boophilus with low prevalence rate 1.53\% while management system of LRS in Islamabad was found satisfactory with no tick prevalence and rural areas of Islamabad was not satisfactory with 23\% of tick prevalence ration. It was concluded from the study that ticks were present in the crossbred cattles of pre-urban areas specially Malpur region of Islamabad with low management system, so there is a need of proper monitoring and management in the pre-urban areas.
\end{abstract}

Conclusion: Key steps should be taken for good managements regarding large animals while special care must be taken for small animals. Proper spray must be carried out for the removal of pathogenic species.

Keywords: Dairy forms, Ticks, Cattles, Buffaloes

\section{Background}

Arthropods and insects probably have evolved about 600 million years ago and 300 million years earlier than the warm-blooded vertebrates. The ticks have worldwide distribution, and their species diversity is greatest in tropical and subtropical regions. Ixodid ticks are obligatory bloodsuckers that they need an animal host to survive and reproduce. Ticks can be a nuisance; their bite can cause irritation and even paralysis, in case of some ticks. Severe infestations on animals can cause anemia, weight loss, and even death due to consumption of large quantities of blood. Ticks and tick-borne diseases affect animal and human health worldwide and are the reason of significant economic losses. They are currently considered to be

\footnotetext{
* Correspondence: zahidanwarktkt2@gmail.com

Main Adnan and all athours have contributed equally to the manuscript. But Zawar Ahmed is the main contributor to the manuscript.

${ }^{1}$ Faculty of Animal Genomics and Biotechnology, PARC Institute of Advanced Studies in Agriculture, National Agricultural Research Center, Islamabad 45500, Pakistan Full list of author information is available at the end of the article
}

second vectors of human infectious diseases in the world after mosquitoes (McCosker, 1979). In recent decades, parasitism has remained one of the major problems of dairy industry in Pakistan. In this context, the most common tick species prevailing are Hyalomma, Boophilus, Haemaphysalis, and Rhipicephalus (Durrani \& Shakoori, 2009). The two types of losses are important, i.e., direct loss due to anemia and skin/hide damage and indirect loss due to transmission of disease as vector. Ticks are transmitting viral, bacterial, and protozoan pathogens causing diseases like hemorrhagic fever, ehrlichiosis, anaplasmosis, theileriosis, and babesiosis in meat and dairy animals (Rajput, Hu, Chen, Arijo, \& Xiao, 2006). In Pakistan during this decade, parasitism is burning issue which causes health problems in domestic animal production, based on climate, water availability, land use, and physiographic parts of Pakistan which offer favorable environmental conditions for ticks, which can infest a variety of hosts and transmit diseases to humans, livestock, and companion animals (Durrani \& Shakoori, 2009). Estimation of blood 
loss varies according to the species under consideration. A single adult female tick may remove $0.5-2.0 \mathrm{ml}$ of blood (Pegram \& Chizyuka, 1990). The ticks suck host blood throughout their lengthy attachment phase of 7-14 days, which may be extended depending on the tick species and unique host association (El Hakim, Shahein, Aboelella, \& Selim, 2007). Optimal temperature and relative humidity required for growth and the reproduction of ticks is $26-37^{\circ} \mathrm{C}$ and $85 \%$, respectively (Aktas, Dumanli, \& Angin, 2004; Yakhachali \& Hosseine, 2006). About 80\% of the world cattle population is infested with ticks (Bowman, Dillwith, \& Sauer, 1996). Food and Agricultural Organization of the United Nations estimated the global losses of hard tick infestation to be US \$ 7.0 billion annually (Harrow, Gration, \& Evans, 1991). Tick infestation diminishes quality of skin/hide up to 2030\% (Gharbi, Sassi, Dorchies, \& Darghouth, 2006) and causes severe anemia, loss of production, weakness, and immunosuppression in the infected animals (Gwakisa et al., 2001). Ticks are voracious blood suckers; loss of blood for their rapid development impoverishes the hosts. In heavy infestation, cattle must have more feed merely to meet the demands of the parasites; the growth of young animals is retarded, and they may remain thin, weak, and stunted. In dairy cows, milk production is greatly reduced (Barnett, 1961). Economic losses are mainly due to the diseases which ticks transmit (Garcia, 2003), financial losses associated with nagging irritation, and depreciation of the value of the skin and hide (up to $20-30 \%$ ) are also significant (Biswas, 2003). Ticks show a variety of host-contact patterns during their lifecycles. In one host tick species (e.g., Boophilus microplus), each developmental stage (larva, numph, and adult) feeds upon the same host individual. In others, two or three individuals are used, with the ticks leaving the host when replete to molt. In three host tick species (e.g., Hyalomma anatolicum anatolicum), a different individual is used for each stage in the cycle, i.e., larva, nymph, and adult, and one blood meal is taken on each host (Wakelin, 1984). An integrated control strategy based on the measures of housing in tick proof buildings, slow burning of the wastes near the walls of the animal sheds, separate housing of cattle and buffaloes, quarantine by using acaricides so that they are free from ticks before adding them to the existing herd, pasture spelling and rotational grazing, and manual removal of ticks is recommended for the control of ticks in cattle (Muhammad, Naureen, Saqib, \& Faryal, 2008).

Knowing the importance of ticks, this study was conducted with following objectives:

- To detect fauna of ticks among cattle and buffaloes of Islamabad.

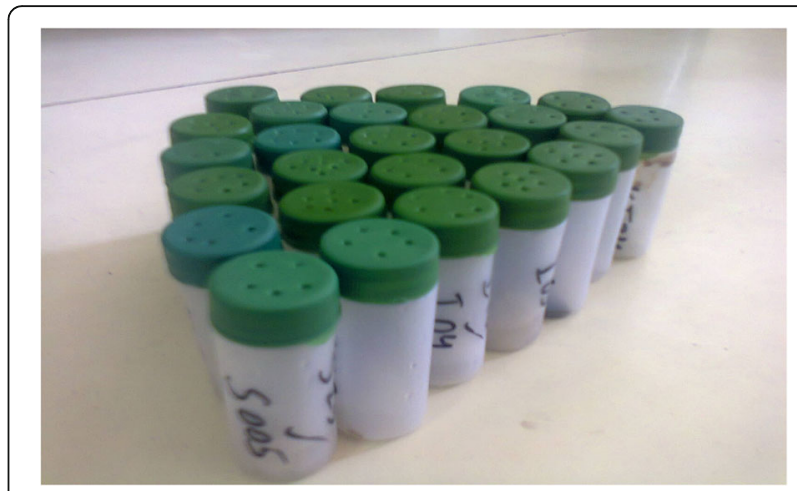

Fig. 1 Ticks collected in plastic bottles

- To find the prevalence among cattle and buffaloes with respect to species, breed, infestation level, and herd size.

\section{Materials and methods}

A cross-sectional study was conducted in peri-urban dairy farms of Islamabad region in September 2015.

\section{Sample collection}

The ticks were collected randomly and snowball sampling in the morning and the evening from 96 cattles and 100 buffaloes in peri-urban dairy farms of Islamabad. The ticks were collected systemically using small forceps as per (Muhammad et al., 2008) starting from the head towards the tail direction and placed in a Petri dish. Care was kept in mind to avoid decapitulation and shedding of the legs.

From Petri dishes, ticks were transferred in plastic bottles. Five to seven holes were made in cap of these plastic bottles for proper aeration, and moisture level was maintained by soaking of cotton swab with water inside the bottle (Hayat \& Akhtar, 1999). The tick samples were brought to parasitology section of the National Veterinary Laboratories NVL, Islamabad, in clean, dry, and properly labeled plastic bottles (Fig. 1).

\section{Categorization of infestation level}

Tick infestation level was categorized as suggested by (Muhammad et al., 2008).

Table 1 Area wise prevalence rate

\begin{tabular}{llll}
\hline Location & $\begin{array}{l}\text { No of animals } \\
\text { examined }\end{array}$ & $\begin{array}{l}\text { No of animals } \\
\text { infested }\end{array}$ & Prevalence \% \\
\hline Bhara Kahu & 23 & 2 & 1.02 \\
Chatha Bakhtawar & 34 & 4 & 2.04 \\
Malpur & 44 & 17 & 8.67 \\
LRS & 96 & 0 & 0.00 \\
Total & 196 & 23 & 11.73 \\
\hline
\end{tabular}


Table 2 Genera wise prevalence rate

\begin{tabular}{llll}
\hline Genera & $\begin{array}{l}\text { No. animals } \\
\text { examined }\end{array}$ & $\begin{array}{l}\text { No. of animals } \\
\text { infested }\end{array}$ & Prevalence \% \\
\hline Hyalomma & 196 & 13 & 6.63 \\
Rhipicephalus & 196 & 7 & 3.57 \\
Boophilus & 196 & 3 & 1.53 \\
\hline
\end{tabular}

$1-25$ ticks $=$ low infestation

26-50 ticks $=$ moderate infestation

$>50$ ticks $=$ high infestation

\section{Sample processing}

Ticks were boiled in $10 \% \mathrm{KOH}$ solution in test tube over the flame for cleaning of abdomen and ease of examination. The collected ticks were identified on dissection microscope based on morphology with the help of the keys (Foreyt, 2001.; Solusby, 1982; Urquhart et al., 1996).

\section{Statistical analysis}

The data was analyzed using simple descriptive statistics derive from the information about the mean of the infestation level and prevalence percentage of infected animals.

\section{Results and discussion}

\section{Species wise tick prevalence in cattle and buffaloes}

The prevalence of ticks was higher (20.83\%) in cattle as compared to buffaloes (3.00\%) as shown in Table 1. The results are near to Soomro et al., 2014 while not relevant with Khan et al., 2013. Tick infestation status was found higher in hot arid areas. TIR in these areas was higher due to the favorable climatic conditions (humidity and temperature). In some parts of the world, there is a possibility to relate the disease incidence to climate change and also a positive association of incidence with mild warm, humid summer, and winter (Bennet, Halling, \& Berglund, 2006). The difference might be due to different climatic conditions, small sample size, and season.

\section{Breed wise tick prevalence in cattle}

Breed wise tick prevalence showed that crossbred cattle were heavily infested (39.53\%) while pure bred indigenous cattle were mildly infested (3.03\%) as shown in Table 2. Low infestation in indigenous cattle is due to immunity acquired over the time while crossbred cattle lacks immunity for ticks.

Table 3 Different animals prevalence rate

\begin{tabular}{llll}
\hline Species & $\begin{array}{l}\text { No. of animals } \\
\text { examined }\end{array}$ & $\begin{array}{l}\text { No. of animals } \\
\text { infested }\end{array}$ & Prevalence \% \\
\hline Cattle & 96 & 20 & 20.83 \\
Buffalo & 100 & 3 & 3.00 \\
\hline
\end{tabular}

Table 4 Breed wise prevalence rate

\begin{tabular}{llll}
\hline Breed & $\begin{array}{l}\text { No. of animals } \\
\text { examined }\end{array}$ & $\begin{array}{l}\text { No. of animals } \\
\text { infested }\end{array}$ & Prevalence \% \\
\hline Cross & 43 & 17 & 39.53 \\
Sahiwal & 33 & 1 & 3.03 \\
Dhani & 4 & 2 & 50.00 \\
Frisean & 3 & 0 & 0.00 \\
Frisean X Sahiwal & 13 & 0 & 00.00 \\
\hline
\end{tabular}

Tick prevalence in cattle and buffaloes

Overall prevalence of ticks was found as $11.3 \%$ whereas no ticks were found from LRS farm, and Malpur farm showed higher prevalence (8.67\%) as shown in Table 3. The results of the present study are not in accordance with the former studies of (Sajid, Iqbal, Khan, \& Muhammad, 2008., Atif, Khan, Iqbal, Ali, \& Ullah, 2012, Khan et al., 2013., Soomro et al., 2014) which may be due to the difference of sample size and variation in season.

\section{Tick genera identified on cattle and buffaloes}

Three tick genera found were Hyalomma, Rhipicephalus, and Boophilus in the study as shown in the table. The result of present study is relevant with (Sajid et al., 2008; Atif et al., 2012, Khan et al., 2013, Soomro et al., 2014.)

\section{Management system wise prevalence in cattle and buffaloes}

Prevalence of ticks was found 23\% from rural areas of Islamabad whereas no ticks were found from LRS farm as shown in Table 4. The difference of tick prevalence between two management systems is due to management practices involved in rearing Table 5.

\section{Conclusion}

$\checkmark$ Ticks were present in peri-urban locality at $11.73 \%$, while LRS animals were free from ticks.

$\checkmark$ Ticks were more prevalent in cattle as compared to buffaloes.

$\checkmark$ Low infestation level was more prevalent followed by moderate and high infestation.

$\checkmark$ Crossbred animals were more infested with ticks as compared to indigenous and other breeds.

$\checkmark$ Malpur study site animals were heavily infested among all study sites.

Table 5 Location wise prevalence rate

\begin{tabular}{llll}
\hline $\begin{array}{l}\text { Management } \\
\text { system }\end{array}$ & $\begin{array}{l}\text { No. of animals } \\
\text { examined }\end{array}$ & $\begin{array}{l}\text { No. of animals } \\
\text { infested }\end{array}$ & Prevalence \% \\
\hline LRS, Islamabad & 96 & 00 & 0.00 \\
Rural Islamabad & 100 & 23 & 23 \\
\hline
\end{tabular}




\section{Recommendations}

Good management practices accounts for tick eradication in large animals.

Regular spray should be carried out on animals and inside crevices of shed.

Owners of small ruminants should take special care of their animals.

Crossbred animals need special attention for tick eradication.

\section{Abbreviations}

NVL: National Veterinary Laboratories; TIR: Tick infestation rate

\section{Acknowledgements}

The authors of manuscript are highly thankful to the staff of Parasitology Section National Veterinaries Laboratories and management of Livestock research station, and owner of sites of studies in Islamabad.

\section{Funding}

Egyptian German Society for Zoology.

\section{Availability of data and materials}

Please contact authors for data requests.

\section{Authors' contributions}

The authors contributed in different aspects. They help each other in sampling and laboratory work. All authors read and approved the final manuscript.

\section{Ethics approval}

This study consists of animal related to human study. So, this study was ethically approved by the committee of Department of Zoology, Kohat University of Science and Technology Pakistan and Veterinary Research Institute Peshawar, Pakistan.

\section{Consent for publication}

There is no any individual's person data in any form.

\section{Competing interests}

The authors declare that they have no competing interests.

\section{Publisher's Note}

Springer Nature remains neutral with regard to jurisdictional claims in published maps and institutional affiliations.

\section{Author details}

${ }^{1}$ Faculty of Animal Genomics and Biotechnology, PARC Institute of Advanced Studies in Agriculture, National Agricultural Research Center, Islamabad 45500, Pakistan. ${ }^{2}$ MOE Key Laboratory of Cell Activities and Stress Adaptations, School of Life Sciences, Lanzhou University, Lanzhou 730000, People's Republic of China. ${ }^{3}$ Department of Animal Nutrition, University of Agriculture Peshawar, Peshawar 25120, Pakistan.

Received: 21 September 2018 Accepted: 11 December 2018

Published online: 19 February 2019

\section{References}

Aktas, M., Dumanli, N., \& Angin, M. (2004). Cattle infestation by Hyaloma ticks and prevalence of Theileria in Hyalomma species in the East of Turkey. Journal of Veterinary Parasitology, 119(1), 1-8.

Atif, F. A., Khan, M. S., lqbal, H. J., Ali, Z., \& Ullah, S. (2012). Prevalence of cattle tick infestation in three districts of the Punjab, Pakistan. Pakistan Journal of Science, 64(1), 49.

Barnett, S. F. (1961). The control of ticks on livestock. Rome, Italy: Food and Agriculture Organization of the United Nations.

Biswas, S. (2003). Role of veterinarians in the care and management during harvest of skin in livestock species, (pp. 62-64). Kolkata, India: Proc. National Seminar on Lather Industry in Today's Perspective.
Bowman, A. S., Dillwith, J. W., \& Sauer, J. R. (1996). Tick salivary prostaglandins: presence, origin and significance. Parasitology Today, 12, 388-396.

Durrani, A. Z., \& Shakoori, A. R. (2009). Study on ecological growth conditions of cattle Hyalomma ticks in Punjab, Pakistan. Iranian Journal of Parasitol, 4(1), $19-25$.

Foreyt, W. J. (2001). Veterinary parasitology. Reference manual. 5th Ed. IOWA state press.

Garcia, Z. (2003). Integrated control of Boophilus microplus in cattle. Mexico city, Mexico: Proc. 11th Int. Congr. Int. Society for Animal Hygiene.

Gharbi, M., Sassi, I., Dorchies, P., \& Darghouth, P. (2006). Infection of calves with Theileria annulata in Tunasia: economic analysis and evaluation of the potential benefit of vaccination. Veterinary Parasitology, 137, 231-241.

Gwakisa, P., Yoshihara, K., Long, T. T., Gotoh, H., Amano, F., \& Eiichi, M. (2001). Salivary gland extract of Rhipicephalus appendiculatus ticks inhibits in vitro transcription and secretion of cytokines and production of nitric oxide by LPS stimulated JA-4 cells. Veterinary Parasitology, 99, 53-61.

El Hakim, A. E., Shahein, Y. E., Aboelella, A. M. K., \& Selim, M. E. (2007). Purification and characterization of two larval glycoproteins from cattle tick Boophilus annulatus. Journal of Veterinary Science, 8(2), 175-180.

Bennet, L., A.Halling and Berglund. J. 2006. Increased incidence of Lyme borreliosis in southern Sweden following mild winters and during warm, humid summers. European Journal of Clinical Microbiology and Infectious Diseases, 25: 426-432.

Harrow, I. D., Gration, K. A. F., \& Evans, N. (1991). Neurobiology of arthropod parasites. Veterinary Parasitology, 102, 559-569.

Khan, A., M. H. Mushtaq., M. Ahmad., Y. Tipu., A. Khan and Munibullah (2013). Tick Infestation rate in cattle and buffalo in different areas of Khyber Pakhtunkhwa, Pakistan. J. Vet. Anim. Sci, 3(1-2), 31-35.

McCosker, P. J. (1979). Global aspects of the management and control of ticks of veterinary importance. Recent AdvAcarol, 2, 45-53.

Muhammad, G., Naureen, A., Saqib, M., \& Faryal, S. (2008). Tick control strategies in dairy production medicine. Pakistan Veterinary Journal, 28, 43-50.

Pegram, R. G., \& Chizyuka, H. G. B. (1990). The impact of natural infestation of ticks in Zambia on the productivity of cattle and implications of tick control strategies in Africa. Parasitologia, 32, 165-176.

Rajput, Z. I., Hu, S., Chen, W., Arijo, A. G., \& Xiao, C. (2006). Importance of ticks and their chemical and immunological control in livestock. Journal of Zhejiang University Science, 7(11), 912-921.

Sajid, M. S., lqbal, Z., Khan, M. N., \& Muhammad, G. (2008). Point prevalence of hard ticks (ixodids) infesting domestic ruminants of lower Punjab, Pakistan. International Journal of Agricultural Biology, 10, 349-351.

Solusby, E. J. L. (1982). Helminths, arthropods and protozoa of domesticated animals, (7th ed., ). London, UK: Bailliere Tindall.

Soomro, M. H., Soomro, S. P., Bhutto, M. B., Akbar, Z., Yaqoob, M., \& Aarijo, A. G. (2014). Prevalence of ticks in buffaloes in the upper Sindh Pakistan. Buffalo Bulletin, 33: 323-327.

Urquhart, G. M., Armur, J., Duncan, J. L., \& Jennings, F. W. (1996). Veterinary Parasitology, UK: Blackwell Science Ltd.

Wakelin, D. (1984). Immunity to parasites, (pp. 134-142). Baltimore, USA: Eward Arnold pub. Ltd.

Yakhachali, M., \& Hosseine, A. (2006). Prevalence and ectoparasites fauna of sheep and goats flocks in Urmia suburb, Iran. Veterinarski arhiv, 76(5), 431-442.

\section{Submit your manuscript to a SpringerOpen ${ }^{\circ}$ journal and benefit from:}

- Convenient online submission

- Rigorous peer review

- Open access: articles freely available online

- High visibility within the field

- Retaining the copyright to your article

Submit your next manuscript at $\boldsymbol{\nabla}$ springeropen.com 